\title{
Prediction of wheat yield using spectral reflectance indices under different tillage, residue and nitrogen management practices
}

\author{
Sujan Adak ${ }^{1}$, K. K. Bandyopadhyay ${ }^{1, *}$, R. N. Sahoo ${ }^{1}$, N. Mridha ${ }^{2}$, \\ M. Shrivastava ${ }^{3}$ and T. J. Purakayastha ${ }^{4}$ \\ ${ }^{1}$ Division of Agricultural Physics, Indian Agricultural Research Institute, New Delhi 110 012, India \\ ${ }^{2}$ National Institute of Research on Jute and Allied Fibre Technology, Kolkata 700 040, India \\ ${ }^{3}$ Centre for Environment Sciences and Climate Resilient Agriculture, Indian Agricultural Research Institute, New Delhi 110012 , India \\ ${ }^{4}$ Division of Soil Science and Agricultural Chemistry, Indian Agricultural Research Institute, New Delhi 110012 , India
}

Effect of tillage, residue mulch and nitrogen management on canopy spectral reflectance indices and their potential to predict the grain and biomass yield of wheat in advance were studied in a field experiment conducted at the Indian Agricultural Research Institute, New Delhi during 2016-17 and 2017-18. The canopy reflectance was measured using a hand-held ASD FieldSpec spectroradiometer at booting, milking and dough stage of wheat. Then 38 hyperspectral structural indices were recorded using the spectral reflectance data and correlated with wheat yield. It was observed that correlation of these indices with wheat grain and biomass yield was maximum for the booting stage. Among the 38 indices recorded at the booting stage, 13 showed significantly higher correlation with grain yield and 10 indices with biomass yield of wheat $(r \geq 0.8)$. Regression models were developed between grain and biomass yield of wheat with these identified spectral indices recorded at booting stage for 2016-17. Validation of these regression models during 2017-18 showed that normalized difference red edge index (NDREI)-based model performed best for grain and biomass prediction. It could account for maximum $76.4 \%$ and $84.3 \%$ variation in the observed grain and biomass yield of wheat with root mean square error of $37.8 \%$ and $50.5 \%$ of the corresponding mean values respectively. Thus the regression models based on NDREI recorded at booting stage can be successfully used for the prediction of grain and biomass yield of wheat in advance.

Keywords: Canopy reflectance, regression models, spectral indices, wheat, yield prediction.

WHEAT (Triticum aestivum L.) is the second most important cereal crop in India, contributing nearly one-third of the total foodgrain production. Different tillage practices and crop residue mulching strongly influence soil properties, crop productivity and environment quality ${ }^{1-3}$. Con-

*For correspondence. (e-mail: kk.bandyopadhyay@gmail.com) servation agriculture system, which maintains high soil surface coverage and least soil disturbance, has caused a significant improvement in soil health ${ }^{4}$, root growth ${ }^{5}$, and water and nutrient use efficiency ${ }^{6}$, which influence crop productivity $^{7}$. Mulching has emerged as a useful technology for storing water in situ by reducing evaporation and facilitating infiltration into the soil profile for its utilization for crop growth, modification of soil hydrothermal regime and improving crop yield ${ }^{8}$. Among the macronutrients, nitrogen is the most critical for wheat production ${ }^{9}$. However, optimization of different inputs like tillage, crop residue mulching, nutrient and water management according to the crop requirement is essential for improving crop growth without compromising soil health and environmental quality. Different crop models help take critical decisions for optimization of these inputs and predict crop yield, but these are dataintensive.

Estimation of crop yield in advance is important for government agencies, trade and industry for planning storage, distribution, processing and export/import of crop produce and efficient management of the agricultural inputs. Prediction of wheat yield under different management practices like tillage, residue mulch and nutrient management can also help in optimal use of inputs and natural resources. In order to get best result in the estimation or prediction of crop yield, the growth of crops has to be monitored throughout the growing season. Remote sensing can be used to provide information on the actual status of agricultural crops on a regular basis in real time. Besides crop simulation models, canopy spectral reflectance is used to predict grain and biomass production of different crops on a regional scale ${ }^{10-13}$. The simple ratio index and normalized difference vegetation index (NDVI) are more commonly used for morpho-physiological study of crops $^{14}$. Raun et al. ${ }^{15}$ reported that NDVI could be used for the prediction of grain yield in winter wheat. Many other vegetation indices have also been used to predict wheat yield ${ }^{16,17}$. NDVI, wide dynamic range vegetation index and vegetation condition index have been 
used to forecast wheat yield in 36 districts of Punjab, India $^{18}$. Pradhan et al. $^{19}$ found that green normalized difference vegetation index (GNDVI), red normalized difference vegetation index (RNDVI) and simple ratio (SR) had a positive correlation whereas water index (WI) had a negative correlation with the grain and biomass yield of wheat. Bandyopadhyay et al. ${ }^{20}$ found that normalized water index-1 (NWI-1) and WI at milking stage could satisfactorily predict the wheat grain and biomass yield with $R^{2}$ value of 0.87 and 0.89 respectively. Chandel et $a l .{ }^{9}$ reported that NDVI at heading stage could account for $96 \%$ variation in the observed grain and biomass yield in irrigated wheat. The relationship of various spectral reflectance indices with plant and environmental variables needs to be analysed using robust regression analysis ${ }^{21}$. Various combinations of bands have been used to account for variations in crop conditions due to agronomical practices, climatic factors, nutrient management and soil characteristics ${ }^{22}$. However, there are limited studies on the role of these indices for the prediction of wheat grain and biomass yield under different tillage, residue and nitrogen management practices.

Bare soil and crop residues show different spectralradiometric responses ${ }^{23,24}$. Hence different tillage practices with varied crop residue cover will necessarily alter the spectral characteristics of the crop background. Spectral properties of background, especially with low vegetation cover can significantly influence the ratio-based vegetation indices, such as NDVI and ratio vegetation index $(\mathrm{RVI})^{25,26}$. This constraint can be partly addressed by the soil-adjusted vegetation indices such as transformed soil-adjusted vegetation index $(\text { TSAVI })^{27}$ and second soil-adjusted vegetation index (SAVI2) ${ }^{28}$; most of them were developed to adjust soil brightness effects. Hyperspectral vegetation indices such as first derivative at the red edge (dRE) and red edge inflection point (REIP) have been reported to perform better than multispectral vegetation indices in reducing the effects of the background ${ }^{29,30}$. However, swapping the background from soil to different levels of residue resulted in considerable changes in both canopy reflectance and vegetation indices when leaf area index varied between 0.1 and 1.0 (ref. 31). Eskandari et al. ${ }^{32}$ attempted to differentiate the tillage systems by crop residue cover on the soil surface and reported that the best index for complete separation of tillage systems was cellulose absorption index (CAI) followed by lignin-cellulose absorption index (LCA) and normalized difference tillage index (NDTI) in a wheat-vetch system.

In this backdrop, the present study was conducted to compare the performance of 38 structural spectral reflectance index-based regression models and identify the best model for prediction of grain and biomass yield of wheat under different tillage, residue and nitrogen management practices.

\section{Materials and methods}

\section{Experimental site}

A field experiment was carried out during rabi season (winter) of 2016-17 and 2017-18 at ICAR-Indian Agricultural Research Institute, New Delhi (lat. $28^{\circ} 35^{\prime} \mathrm{N}$, long. $77^{\circ} 12^{\prime} \mathrm{E}$, altitude $228.7 \mathrm{~m}$ amsl) with wheat crop (Triticum aestivum L.) in an ongoing field experiment being conducted since 2014 . The climate is sub-tropical semi-arid (dry hot summer and brief severe winter). The soil of the study area is sandy loam texture with blocky structure, non-calcareous and slightly alkaline $(\mathrm{pH}=7.9)$ having bulk density $1.58 \mathrm{Mg} \mathrm{m}^{-3}$, hydraulic conductivity $1.04 \mathrm{~cm} \mathrm{~h}^{-1}$, saturated water content $0.45 \mathrm{~m}^{3} \mathrm{~m}^{-3}$, electrical conductivity (soil : water suspension $=1: 2.5$ ) $0.36 \mathrm{dS} \mathrm{m}^{-1}$, organic carbon $4.2 \mathrm{~g} \mathrm{~kg}^{-1}$, total nitrogen $0.034 \%$, available phosphorus (Olsen) $7.2 \mathrm{~kg} \mathrm{ha}^{-1}$ and available potassium $285.0 \mathrm{~kg} \mathrm{ha}^{-1}$.

\section{Experimental set-up}

The experiment was designed in a split-split plot with three replications. There were two types of tillage (conventional tillage (CT) and no tillage (NT)) as the main plot factor, two levels of surface mulch (with maize straw $(\mathrm{R}+)$ and without mulch $(\mathrm{R} 0))$ as the sub-plot factor and three doses of nitrogen $\left(60 \mathrm{~kg} \mathrm{~N} \mathrm{ha}^{-1}(\mathrm{~N} 60), 120 \mathrm{~kg} \mathrm{~N}^{-1}\right.$ (N120) and $180 \mathrm{~kg} \mathrm{~N} \mathrm{ha}^{-1}(\mathrm{~N} 180)$ ) as the sub-sub plot factor. Wheat (cv. HD 2967) was grown in the rabi season (third week of November to third week of April) of 2016-17 and 2017-18. Application of nitrogen was done in three splits, i.e. $50 \%, 25 \%$ and $25 \%$ of $\mathrm{N}$ was applied at sowing, crown root initiation (CRI) and flowering stage respectively. A uniform dose of $\mathrm{P}_{2} \mathrm{O}_{5}\left(60 \mathrm{~kg} \mathrm{ha}^{-1}\right)$ as SSP and $\mathrm{K}_{2} \mathrm{O}\left(60 \mathrm{~kg} \mathrm{ha}^{-1}\right)$ as MOP was applied in all plots as basal dose at sowing. Five irrigations were applied at critical growth stages, viz. CRI, tillering, jointing, flowering and milk stage to all the plots.

\section{Spectral reflectance measurements}

The reflectance of wheat canopy was captured in the spectral range $350-1800 \mathrm{~nm}$ with a bandwidth of $1 \mathrm{~nm}$ using handheld ASD FieldSpec spectroradiometer. The reflectance was measured at noon $(11.00-13.00 \mathrm{~h})$ on sunny days. The field of view (FOV) of the spectroradiometer was $25^{\circ}$ and $1 \mathrm{~m}$ distance was maintained between the top of the plant and optical head of the instrument. Prior to the canopy spectral reflectance measurement, a spectralon (white panel) was employed to acquire reference signal to optimize the spectroradiometer. The ratio of canopy reflectance to reflectance from the white reference panel was used for the computation of canopy reflectance. Spectral reflectance of the wheat 
Table 1. Spectral reflectance indices used in this study

\begin{tabular}{|c|c|c|}
\hline Index & Formula & Reference \\
\hline Carter index $1(\mathrm{Ctr} 1)$ & $R_{760} / R_{695}$ & Carter $^{50}$ \\
\hline Curvature index & $R_{675}\left(R_{690} / R_{683}^{2}\right)$ & Zarco-Tejada et al. ${ }^{51}$ \\
\hline Curvature index 1 & $R_{440} / R_{690}$ & Zarco-Tejada et al. ${ }^{51}$ \\
\hline Gitelson and Merzlyak index (GMI) & $R_{750} / R_{550}$ & $\begin{array}{l}\text { Gitelson and } \\
\text { Merzlyak }^{52}\end{array}$ \\
\hline Green index (GI) & $R_{554} / R_{677}$ & Zarco-Tejada et al..$^{51}$ \\
\hline Green vegetation index (GVI) & $\left(R_{682}-R_{553}\right) /\left(R_{682}+R_{553}\right)$ & Kauth and Thomas ${ }^{53}$ \\
\hline Lichtenthaler indices (Lic1) & $\left(R_{790}-R_{680}\right) /\left(R_{790}+R_{680}\right)$ & Lichtenthaler et al. ${ }^{54}$ \\
\hline Lichtenthaler indices (Lic2) & $R_{440} / R_{690}$ & Lichtenthaler et al. ${ }^{54}$ \\
\hline Modified normalized difference vegetation index (mNDVI) & $\left(R_{800}-R_{680}\right) /\left(R_{800}+R_{680}-2 R_{445}\right)$ & Sims and Gamon ${ }^{55}$ \\
\hline Modified normalized difference 705 (mND_705) & $\left(R_{750}-R_{705}\right) /\left(R_{750}+2 R_{445}\right)$ & Datt $^{56}$ \\
\hline Modified simple ratio (MSR) & $\left(R_{800} / R_{670}-1\right) /\left[\left(R_{800} / R_{670}\right)+1\right]$ & Chen $^{57}$ \\
\hline Modified soil-adjusted vegetation index (MSAVI) & $0.5 *\left\{2 R_{800}+1-\left[\left(2 R_{800}+1\right)^{2}-8\left(R_{800}-R_{670}\right)\right]^{0.5}\right\}$ & Qi et $a l .{ }^{58}$ \\
\hline Modified triangular vegetation index (MTVI) & $1.2\left[1.2\left(R_{800}-R_{550}\right)-2.5\left(R_{670}-R_{550}\right)\right]$ & Haboudane et al. ${ }^{59}$ \\
\hline $\begin{array}{l}\text { Modified red edge normalized difference vegetation index } \\
\text { (MRENDVI) }\end{array}$ & $\left(R_{750}-R_{705}\right) /\left(R_{750}+R_{705}-2 * R_{445}\right)$ & Sims and Gamon ${ }^{55}$ \\
\hline Modified red edge simple ratio (MRESR) & $\left(R_{750}-R_{445}\right) /\left(R_{705}-R_{445}\right)$ & Sims and Gamon ${ }^{55}$ \\
\hline Normalized difference red edge index (NDREI) & $\left(R_{790}-R_{720}\right) /\left(R_{790}+R_{720}\right)$ & Rodriguez et al. ${ }^{60}$ \\
\hline Normalized difference vegetation index (NDVI) & $\left(R_{830}-R_{670}\right) /\left(R_{830}+R_{670}\right)$ & Rouse et $a l .{ }^{61}$ \\
\hline Normalized difference water index (NDWI) & $\left(R_{857}-R_{1241}\right) /\left(R_{857}+R_{1241}\right)$ & McFeeters ${ }^{62}$ \\
\hline Optimized soil-adjusted vegetation index (OSAVI) & $(1+0.16) *\left(R_{800}-R_{670}\right) /\left(R_{800}+R_{670}+0.16\right)$ & Rondeaux et al. ${ }^{63}$ \\
\hline Perpendicular vegetation index (PVI) & $\begin{array}{l}\left(R_{\mathrm{NIR}}-\alpha R_{\mathrm{red}}-b\right) /(1+\alpha 2) \\
R_{\mathrm{NIR}}, \text { soil }=\alpha R_{\mathrm{red}}, \text { soil }+b\end{array}$ & $\begin{array}{l}\text { Richardson and } \\
\text { Wiegand }^{64}\end{array}$ \\
\hline Photochemical reflectance index (PRI) & $\left(R_{531}-R_{570}\right) /\left(R_{531}+R_{570}\right)$ & Garbulsky et al. ${ }^{65}$ \\
\hline Plant senescence reflectance index (PSRI) & $\left(R_{680}-R_{500}\right) / R_{750}$ & Merzlyak et $a l .{ }^{66}$ \\
\hline Ratio index-1dB (RI_1dB) & $R_{735} / R_{720}$ & Gupta et al. ${ }^{67}$ \\
\hline Ratio index-2dB (RI_2dB) & $R_{738} / R_{720}$ & Gupta et al. ${ }^{67}$ \\
\hline Ratio index-Half (RI_half) & $R_{747} / R_{708}$ & Gupta et al. ${ }^{67}$ \\
\hline Red green index $(\mathrm{RGI})$ & $R_{690} / R_{550}$ & Zarco-Tejada et al. ${ }^{51}$ \\
\hline Red-Edge Position (REP) & $700+\left[40\left(R_{670}+R_{780}\right) / 2-R_{700}\right] /\left(R_{740}-R_{700}\right)$ & Guyot et al. ${ }^{68}$ \\
\hline $\begin{array}{l}\text { Red edge normalized difference vegetation index } \\
\text { (RENDVI) }\end{array}$ & $\left(R_{750}-R_{705}\right) /\left(R_{750}+R_{705}\right)$ & $\begin{array}{l}\text { Gitelson and } \\
\text { Merzlyak }^{69}\end{array}$ \\
\hline Renormalized difference vegetation index (RDVI) & $\left(R_{800}-R_{670}\right) /\left[\left(R_{800}+R_{670}\right)^{0.5}\right]$ & Roujean and Breon ${ }^{70}$ \\
\hline Second modified triangular vegetation index (MTVI2) & $\begin{array}{l}{\left[1.5\left(1.2 *\left(R_{800}-R_{550}\right)-2.5\left(R_{800}-R_{550}\right)\right] /\left[\left(\left(2 R_{800}+1\right)^{2}\right.\right.\right.} \\
\left.\left.\quad-\left(6 R_{800}-5\left(R_{650}\right)^{0.5}\right)\right)^{0.5}-0.5\right]^{0.5}\end{array}$ & Haboudane et al. ${ }^{59}$ \\
\hline Second soil-adjusted vegetation index (SAVI2) & $\begin{array}{l}R_{852} /\left[R_{1433}+(a / b)\right] \\
\quad b=\text { intercept of the soil line; } a=\text { slope of the soil line }\end{array}$ & Major et al. ${ }^{71}$ \\
\hline Soil-adjusted vegetation index (SAVI) & {$\left[\left(R_{800}-R_{670}\right) /\left(R_{800}+R_{670}+0.5\right)\right] *(1+0.5)$} & Huete $^{72}$ \\
\hline Transformed soil-adjusted vegetation index (TSAVI) & $\begin{array}{l}{\left[\alpha\left(R_{875}-\alpha R_{680}-b\right)\right] /\left[\left(R_{680}+\alpha R_{875}-\alpha b+0.08\left(1+\alpha^{2}\right)\right)\right]} \\
\quad \text { where } \alpha=1.062 \text { and } b=0.022\end{array}$ & Rondeaux et $a l .{ }^{63}$ \\
\hline Triangular vegetation index (TVI) & $0.5\left[120\left(R_{750}-R_{550}\right)-200\left(R_{670}-R_{550}\right)\right]$ & Broge and Leblanc ${ }^{73}$ \\
\hline Vogelmann red edge index 1 (VREI1) & $R_{740} / R_{720}$ & Vogelman et al. ${ }^{74}$ \\
\hline Vogelman red edge index 2 (VREI2) & $\left(R_{734}-R_{747}\right) /\left(R_{715}+R_{726}\right)$ & Vogelman et al..$^{74}$ \\
\hline Water band index (WBI) & $R_{900} / R_{970}$ & Penuelas et al..$^{75}$ \\
\hline Zarco-Tejada and Miller index (ZMI) & $R_{750} / R_{710}$ & Zarco-Tejada et al. ${ }^{76}$ \\
\hline
\end{tabular}

$R$ indicates the reflectance and subscripts indicate the specific wavelength (nm).

canopy was measured at three phenostages of wheat (booting, milking and dough stages) during 2016-17 and 2017-18.

\section{Pre-processing of canopy reflectance}

The raw canopy reflectance collected using the spectroradiometer always carries background information and noise. Hence preprocessing of the raw spectral reflectance was done by removing the unusual spectrum, averaging the canopy spectrum and splicing correction. In the present study, the Savitzky-Golay filter was employed to eliminate the effect of noise and background information. The Savitzky-Golay filter operates a moving polynomial fit of any order and the size of the filter is calculated as $(2 n+1)$ points, where $n$ is the half-width of the smoothing window. The points between the $2 n$ s are interpolated by the polynomial fit $^{33}$.

\section{Red edge analysis}

First derivative of mean reflectance was derived and evaluated. Red edge shifts and shapes of the red peak in the first derivative curve were studied for different treatments. 
Wavelength $\left(\lambda_{\text {re }}\right)$ and amplitude $\left(\mathrm{d} r_{\mathrm{re}}\right)$ of the red edge peak for different treatments were analysed. Characterization of spectra under different nitrogen levels was done in relation to the following red edge parameters: $\lambda_{\mathrm{re}}$ is the wavelength of this red edge peak, $\mathrm{d} r_{\mathrm{re}}$ is the maximum amplitude of the red edge peak and $\sum(\mathrm{d} r 670-780)$ is the sum of the first derivative reflectance amplitudes between 670 and $780 \mathrm{~nm}$.

\section{Computation of spectral indices}

Thirty-eight spectral reflectance indices (SRI) were computed from the spectral reflectance for each treatment. Table 1 presents the formulae of SRI used in this study ${ }^{34-60}$. However, in the present study, SRI at booting stage was only used for the prediction of wheat grain and biomass yield because of its higher correlation with grain and biomass yield.

\section{Crop grain and biomass yield}

For the measurement of grain and biomass yield, crop was harvested from two representative areas of $1 \mathrm{~m}^{2}$ each in the centre of each plot to avoid border effect. After cleaning and drying of the grains, the grain yield was expressed at $14 \%$ moisture basis. The wheat grain and biomass yield were expressed in kilogram per hectare.

\section{Model development and validation}

Spectral index-based linear regression models were developed for the prediction of wheat grain and aboveground biomass yield during 2016-17. In the next year, the regression models were validated using the independent datasets (spectral indices) recorded in the year 2017-18. These models were also evaluated to determine how closely a model predicts the actual grain and biomass yield of wheat. The accuracy was judged using parameters like $R^{2}$, mean prediction error, root mean square error (RMSE) and normalized RMSE (nRMSE).

The coefficient of determination $\left(R^{2}\right)$ serves as an indicator of the quality of trend conformity.

$$
\text { Prediction error }(\mathrm{PE})=\left(\left(P_{\mathrm{i}}-O_{\mathrm{i}}\right) / O_{\mathrm{i}}\right) \times 100 \text {, }
$$

where $O_{\mathrm{i}}$ is the observed value and $P_{\mathrm{i}}$ is the predicted value. Prediction is considered to be excellent if the value of PE is near zero.

RMSE was employed to measure the fitness between the estimated and measured values.

$$
\text { RMSE }=\sqrt{\frac{1}{n} \sum_{i=1}^{n}\left(P_{\mathrm{i}}-O_{\mathrm{i}}\right)^{2}}
$$

nRMSE is denoted as RMSE as a percentage of the observed mean value.

$$
\mathrm{nRMSE}=(\operatorname{RMSE} / \bar{O}) \times 100,
$$

where $P_{\mathrm{i}}$ and $O_{\mathrm{i}}$ are the predicted and observed values respectively. Observed mean is denoted by $\bar{O}$ and $n$ is number of samples. nRMSE (\%) shows the relative difference between the predicted and observed data.

\section{Statistical analysis}

The data were statistically analysed using analysis of variance (ANOVA) as applicable to split-split plot design using the SAS software ${ }^{34}$. The $F$-test was used to determine the significance of the treatment effects and difference between the means was estimated using least significance difference at $5 \%$ probability level. Data analysis tool pack of MS Excel (2007) was used to analyse correlations and regressions.

\section{Results}

\section{Grain and biomass yield of wheat}

There was decrease in grain and biomass yield by 23.65 and $34.2 \%$ during 2017-18 compared to 2016-17. Grain and aboveground biomass yield of wheat were not significantly affected by the tillage treatment and residue mulch treatment (Table 2). However, the nitrogen levels significantly $(P \leq 0.05)$ influenced grain and aboveground biomass yield of wheat (Table 2). The wheat grain yield was significantly higher in N180 treatment (3763 $\mathrm{kg} \mathrm{ha}^{-1}$ for 2016-17 and $3008 \mathrm{~kg} \mathrm{ha}^{-1}$ for 2017-18) than the N120 (3403 kg ha ${ }^{-1}$ for 2016-17 and $2805 \mathrm{~kg} \mathrm{ha}^{-1}$ for 2017-18) and N60 (2763 $\mathrm{kg} \mathrm{ha}^{-1}$ for 2016-17 and $2220 \mathrm{~kg} \mathrm{ha}^{-1}$ for 2017-18) treatments. The grain yield in N180 treatment increased by $10.6 \%$ and $7.2 \%$ than N120 for 2016-17 and 2017-18 respectively, whereas it increased by $36.2 \%$ and $35.5 \%$ than N60 for 2016-17 and 2017-18 respectively. The grain yield in N120 increased significantly by $23.1 \%$ and $26.3 \%$ than N60 for $2016-17$ and 2017-18 respectively. Similarly, the aboveground biomass yield of wheat was significantly higher in N180 treatment $\left(10,419 \mathrm{~kg} \mathrm{ha}^{-1}\right.$ for $2016-17$ and $7708 \mathrm{~kg} \mathrm{ha}^{-1}$ for 2017-18) than the N120 (9415 $\mathrm{kg} \mathrm{ha}^{-1}$ for 2016-17 and $7017 \mathrm{~kg} \mathrm{ha}^{-1}$ for 2017-18) and N60 (7553 kg ha-1 for 2016-17 and $5675 \mathrm{~kg} \mathrm{ha}^{-1}$ for 2017-18) treatments. The aboveground biomass yield in N180 treatment increased by $10.7 \%$ and $9.9 \%$ than N120 for $2016-17$ and $2017-18$ respectively, whereas it increased by $37.9 \%$ and $35.8 \%$ than N60 for 2016-17 and 2017-18 respectively. The biomass yield of N120 treatment significantly increased by $24.7 \%$ and $23.6 \%$ than N60 for $2016-17$ and $2017-18$ respectively. 
Table 2. Grain and biomass yield of wheat as influenced by tillage, residue and nitrogen management

\begin{tabular}{|c|c|c|c|c|c|}
\hline \multirow[b]{2}{*}{ Treatment } & & \multicolumn{2}{|c|}{ Grain yield $\left(\mathrm{kg} \mathrm{ha}^{-1}\right)$} & \multicolumn{2}{|c|}{ Biomass yield $\left(\mathrm{kg} \mathrm{ha}^{-1}\right)$} \\
\hline & & $2016-17$ & $2017-18$ & $2016-17$ & $2017-18$ \\
\hline \multicolumn{6}{|l|}{ Effect of tillage } \\
\hline $\mathrm{CT}$ & & $3349^{\mathrm{A \#}}$ & $2778^{\mathrm{A}}$ & $8980^{\mathrm{A}}$ & $6778^{\mathrm{A}}$ \\
\hline NT & & $3270^{\mathrm{A}}$ & $2577^{\mathrm{A}}$ & $9278^{\mathrm{A}}$ & $6822^{\mathrm{A}}$ \\
\hline \multicolumn{6}{|l|}{ Effect of residue } \\
\hline R0 & & $3229^{\mathrm{A}}$ & $2623^{\mathrm{A}}$ & $8786^{\mathrm{A}}$ & $6794^{\mathrm{A}}$ \\
\hline $\mathrm{R}+$ & & $3390^{\mathrm{A}}$ & $2732^{\mathrm{A}}$ & $9472^{\mathrm{A}}$ & $6806^{\mathrm{A}}$ \\
\hline \multicolumn{6}{|l|}{ Effect of nitrogen } \\
\hline N60 & & $2763^{C}$ & $2220^{\mathrm{C}}$ & $7553^{C}$ & $5675^{\mathrm{C}}$ \\
\hline N120 & & $3403^{B}$ & $2805^{\mathrm{B}}$ & $9415^{\mathrm{B}}$ & $7017^{\mathrm{B}}$ \\
\hline N180 & & $3763^{\mathrm{A}}$ & $3008^{\mathrm{A}}$ & $10419^{\mathrm{A}}$ & $7708^{\mathrm{A}}$ \\
\hline $\operatorname{LSD}(\mathrm{T})$ & & NS & NS & NS & NS \\
\hline $\operatorname{LSD}(\mathrm{R})$ & & NS & NS & NS & NS \\
\hline $\mathrm{LSD}(\mathrm{N})$ & & $311.6^{*}$ & $714.2 *$ & $115.3 *$ & $419.9 *$ \\
\hline \multicolumn{6}{|l|}{ ANOVA } \\
\hline Source & DF & $p$-value & $p$-value & $p$-value & $p$-value \\
\hline REP & 2 & 0.7847 & 0.3274 & 0.6837 & 0.9580 \\
\hline MP & 1 & 0.5833 & 0.0782 & 0.4527 & 0.9285 \\
\hline Error (a) & 2 & & & & \\
\hline $\mathrm{SP}$ & 1 & 0.3387 & 0.0906 & 0.3024 & 0.9525 \\
\hline $\mathrm{MP} * \mathrm{SP}$ & 1 & 0.5274 & 0.2038 & 0.9738 & 0.2945 \\
\hline Error (b) & 4 & & & & \\
\hline SSP & 2 & $<0.0001$ & $<0.0001$ & $<0.0001$ & $<0.0001$ \\
\hline $\mathrm{MP} * \mathrm{SSP}$ & 2 & 0.0595 & 0.6982 & 0.0019 & 0.6094 \\
\hline $\mathrm{SP} * \mathrm{SSP}$ & 2 & 0.8534 & 0.3513 & 0.3766 & 0.0709 \\
\hline $\mathrm{MP} * \mathrm{SP} * \mathrm{SSP}$ & 2 & 0.3938 & 0.5932 & 0.1151 & 0.4371 \\
\hline Error (c) & 16 & & & & \\
\hline Total & 35 & & & & \\
\hline
\end{tabular}

"Values in a column followed by the same letters are not significantly different at $P<0.05$ according to DMRT; *Significant at $P<0.05$.

\section{Effect of tillage, residue mulch and nitrogen on canopy reflectance spectra}

Figure 1 presents the canopy reflectance curves of wheat at booting stage as influenced by tillage, residue mulch and nitrogen treatments. It can be observed that there is no significant variation in canopy reflectance due to different tillage (Figure $1 a$ ) and crop residue mulch treatments (Figure $1 b$ ) throughout the spectral region of study $(350-1800 \mathrm{~nm})$. However, the spectral reflectance of wheat canopy under different nitrogen treatments (N60, N120 and N180) showed appreciable difference throughout the spectral region of study $(350-1800 \mathrm{~nm}$ ) (Figure $1 \mathrm{c})$. The canopy reflectance at red band $(680 \mathrm{~nm})$ was lowest for N180 treatment followed by N120 and N60 treatments. However, canopy reflectance at the near infrared (NIR) region was highest for the N180 treatment followed by N120 and N60 treatments.

\section{Effect of tillage, residue mulch and nitrogen doses on red edge spectra}

The red edge area is the region of rapid change in reflectance of vegetation from red to NIR range of the electro- magnetic spectrum (Figure 2). The red edge spectra were not influenced by tillage and residue mulch treatments. However, they were influenced by different nitrogen levels. The red edge area was highest for N180 treatment (0.3669) followed by N120 (0.3175) and N60 (0.2407) treatments. This was evident from the sum of the first derivative reflectance amplitudes between 670 and $780 \mathrm{~nm}$ (Table 3). With the increase in nitrogen doses there was a shift of red edge position, i.e. peak of the first derivative of spectral reflectance curve, towards longer wavelength (red shift; Table 3). Result also showed that the amplitude of the peak and sum of the first derivative reflectance between 670 and $780 \mathrm{~nm}$ gradually decreased with decrease in $\mathrm{N}$ level (increase in $\mathrm{N}$ stress) (Table 3).

\section{Correlation between spectral reflectance indices and grain and biomass yield of wheat}

Correlation between spectral reflectance indices and grain and biomass yield of wheat indicated that among the booting, milk and dough stages, all the spectral indices at booting stage showed highest correlation with the grain and biomass yield of wheat (Table 4). The spectral indices at booting stage were significantly positively correlated 

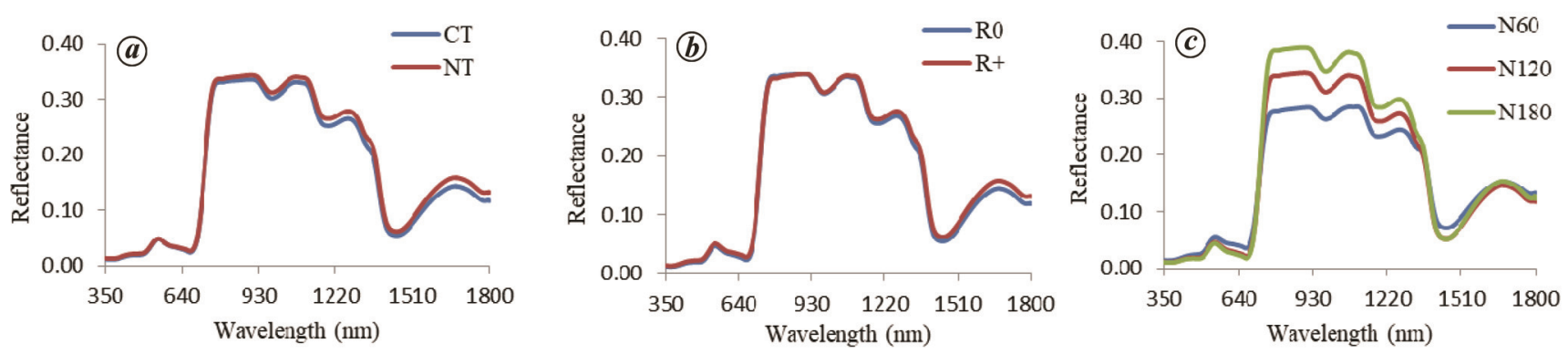

Figure 1. Canopy reflectance spectra as influenced by (a) tillage, (b) residue and (c) N management at booting stage of wheat in $2017-18$.
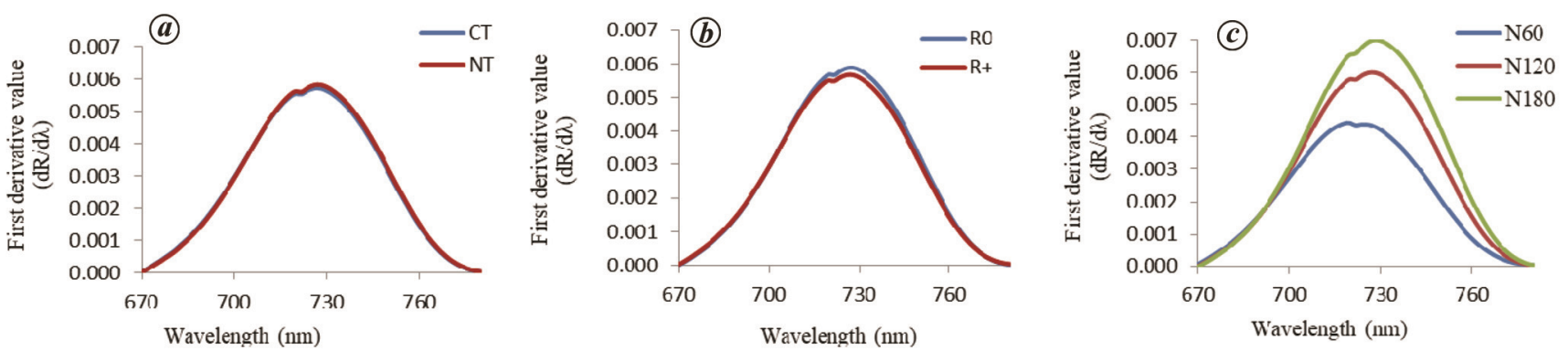

Figure 2. Red edge spectra as influenced by (a) tillage, $(\boldsymbol{b})$ residue and (c) N management at booting stage of wheat in 2017-18.

Table 3. Characteristics of red edge curve under different nitrogen treatments

\begin{tabular}{lccc}
\hline Treatment & $\begin{array}{c}\text { Wavelength of red edge } \\
\text { peak }(\mathrm{nm})\left(\lambda_{\mathrm{re}}\right)\end{array}$ & $\begin{array}{c}\text { Amplitude of red edge peak } \\
\left(\mathrm{REV} ; \mathrm{d} r_{\mathrm{re}}\right)\end{array}$ & $\begin{array}{c}\text { Sum of the first derivative reflectance amplitudes } \\
\text { between } 670 \text { and } 780 \mathrm{~nm}\left(\sum(\mathrm{d} r 670-780)\right)\end{array}$ \\
\hline CT & 727 & 0.005729 & 0.3066 \\
NT & 727 & 0.005837 & 0.3102 \\
R0 & 727 & 0.005890 & 0.3128 \\
R+ & 727 & 0.005676 & 0.3040 \\
N60 & 719 & 0.004445 & 0.2407 \\
N120 & 727 & 0.006007 & 0.3175 \\
N180 & 728 & 0.007001 & 0.3669 \\
\hline
\end{tabular}

with the grain yield, except GVI, MSAVI, PRI, PSRI, RGI, REP and MTVI2, which showed significant negative correlation. At booting stage, normalized difference red edge index (NDREI) showed significantly highest correlation with the grain yield of wheat for 2016-17 $\left(r=0.853^{* *}\right)$. Further, at this stage the modified red edge normalized difference vegetation index (MRENDVI) showed highest correlation with the biomass yield of wheat $\left(r=0.815^{* *}\right)$ during 2016-17. Among the $38 \mathrm{spec}-$ tral indices, 13 and 10 structural indices having correlation coefficient $(r) \geq 0.802$ with the grain and biomass yield of wheat were selected for developing regression models for the prediction of grain and biomass yield respectively.

\section{Effect of tillage, residue mulch and nitrogen on spectral reflectance indices}

The selected 13 SRI at booting stage under different tillage, residue and nitrogen treatments are presented in
Tables 5 and 6 for $2016-17$ and 207-18 respectively. The SRI values were statistically similar for conventional tillage and no tillage treatments. The effect of crop residue mulch on spectral reflectance indices was also not statistically significant. Among the nitrogen treatments, the SRI values under N180 treatment were highest followed by N120 and N60 treatments.

\section{Prediction of grain and biomass yield}

Regression models developed between the selected 13 SRI and grain yield of wheat for 2016-17 showed that spectral indices accounted for 59-73\% variation in the grain yield of wheat (Table 7). The independent datasets of grain yield and SRI recorded during 2017-18 were used to validate these regression models (Table 8). It was observed that the regression models could account for $59-76 \%$ variation in the observed grain yield of wheat during validation. Out of the 13 SRI-based regression models, the NDREI-based model could account for 
Table 4. Correlation between hyperspectral indices at critical growth stages and grain and biomass yield of wheat in 2016-17 across different tillage, residue and nitrogen management practices

\begin{tabular}{|c|c|c|c|c|c|c|}
\hline \multirow[b]{2}{*}{ Index } & \multicolumn{3}{|c|}{ Grain yield } & \multicolumn{3}{|c|}{ Biomass yield } \\
\hline & Booting & Milk & Dough & Booting & Milk & Dough \\
\hline Ctr1 & $0.787 * *$ & $0.727 * *$ & $0.782 * *$ & $0.754 * *$ & $0.714 * *$ & $0.745 * *$ \\
\hline Curvature Index & $0.408^{\mathrm{NS}}$ & $0.374^{\mathrm{NS}}$ & $0.607 *$ & $0.345^{\mathrm{NS}}$ & $0.423^{\mathrm{NS}}$ & $0.507^{\mathrm{NS}}$ \\
\hline Curvature Index 1 & $0.716 * *$ & $0.669^{*}$ & $0.644 *$ & $0.701 *$ & $0.707^{*}$ & $0.554^{\mathrm{NS}}$ \\
\hline GMI & $0.808 * *$ & $0.743 * *$ & $0.803 * *$ & $0.770 * *$ & $0.719 * *$ & $0.766 * *$ \\
\hline GI & $0.531^{\mathrm{NS}}$ & $0.496^{\mathrm{NS}}$ & $0.679 *$ & $0.487^{\mathrm{NS}}$ & $0.552^{\mathrm{NS}}$ & $0.584 *$ \\
\hline GVI & $-0.597 *$ & $-0.505^{\mathrm{NS}}$ & $-0.601 *$ & $-0.534^{\mathrm{NS}}$ & $-0.540^{\mathrm{NS}}$ & $-0.582 *$ \\
\hline Lic1 & $0.770 * *$ & $0.612 *$ & $0.824 * *$ & $0.718 * *$ & $0.588^{*}$ & $0.701 * *$ \\
\hline Lic2 & $0.716^{* *}$ & $0.669^{*}$ & $0.644^{*}$ & $0.701 *$ & $0.707 *$ & $0.554^{\mathrm{NS}}$ \\
\hline mNDVI & $0.762 * *$ & $0.609^{*}$ & $0.759^{* *}$ & $0.698^{*}$ & $0.596^{*}$ & $0.703 * *$ \\
\hline mND_705 & $0.802 * *$ & $0.722^{* *}$ & $0.783^{* *}$ & $0.759 * *$ & $0.685^{*}$ & $0.779 * *$ \\
\hline $\mathrm{MSR}^{-}$ & $0.768 * *$ & $0.609^{*}$ & $0.827^{* *}$ & $0.717 * *$ & $0.584^{*}$ & $0.756 * *$ \\
\hline MSAVI & $-0.708 * *$ & $-0.613^{*}$ & $-0.707 * *$ & $-0.643 *$ & $-0.619 *$ & $-0.762 * *$ \\
\hline MTVI & $0.709 * *$ & $0.596^{*}$ & $0.783^{* *}$ & $0.633^{*}$ & $0.609 *$ & $0.754 * *$ \\
\hline MRENDVI & $0.853 * *$ & $0.765^{* *}$ & $0.829^{* *}$ & $0.815^{* *}$ & $0.727^{* *}$ & $0.756^{* *}$ \\
\hline MRESR & $0.849 * *$ & $0.810^{* *}$ & $0.834 * *$ & $0.810 * *$ & $0.785^{* *}$ & $0.763 * *$ \\
\hline NDREI & $0.853 * *$ & $0.852 * *$ & $0.848 * *$ & $0.814 * *$ & $0.795 * *$ & $0.817 * *$ \\
\hline NDVI & $0.768 * *$ & $0.609^{*}$ & $0.832 * *$ & $0.719 * *$ & $0.584^{*}$ & $0.762 * *$ \\
\hline NDWI & $0.755^{* *}$ & $0.795^{* *}$ & $0.775^{* *}$ & $0.689^{*}$ & $0.727^{* *}$ & $0.632^{*}$ \\
\hline OSAVI & $0.766^{* *}$ & $0.639^{*}$ & $0.820^{* *}$ & $0.707^{*}$ & $0.624^{*}$ & $0.771 * *$ \\
\hline PVI & $0.841 * *$ & $0.744 * *$ & $0.834 * *$ & $0.768 * *$ & $0.764 * *$ & $0.803 * *$ \\
\hline PRI & $-0.730 * *$ & $-0.344^{\mathrm{NS}}$ & $-0.721 * *$ & $-0.750 * *$ & $-0.418^{\mathrm{NS}}$ & $-0.678^{*}$ \\
\hline PSRI & $-0.735^{* *}$ & $-0.550^{\mathrm{NS}}$ & $-0.728 * *$ & $-0.663^{*}$ & $-0.552^{\mathrm{NS}}$ & $-0.665^{*}$ \\
\hline RI_1dB & $0.842 * *$ & $0.817^{* *}$ & $0.828^{* *}$ & $0.796^{* *}$ & $0.769^{* *}$ & $0.779 * *$ \\
\hline RI_2dB & $0.841 * *$ & $0.828 * *$ & $0.830^{* *}$ & $0.796^{* *}$ & $0.778 * *$ & $0.783 * *$ \\
\hline RI_Half & $0.831 * *$ & $0.786^{* *}$ & $0.823 * *$ & $0.790 * *$ & $0.750^{* *}$ & $0.775^{* *}$ \\
\hline $\mathrm{RG}$ & $-0.694 *$ & $-0.520^{\mathrm{NS}}$ & $-0.677^{*}$ & $-0.640^{*}$ & $-0.549^{\mathrm{NS}}$ & $-0.581^{*}$ \\
\hline REP & $-0.765 * *$ & $-0.468^{\mathrm{NS}}$ & $-0.778 * *$ & $-0.736^{* *}$ & $-0.447^{\mathrm{NS}}$ & $-0.697^{*}$ \\
\hline RENDVI & $0.833 * *$ & $0.736 * *$ & $0.829 * *$ & $0.793 * *$ & $0.696^{*}$ & $0.771 * *$ \\
\hline RDVI & $0.760 * *$ & $0.640 *$ & $0.815^{* *}$ & $0.697 *$ & $0.635^{*}$ & $0.775 * *$ \\
\hline MTVI2 & $-0.794 * *$ & $-0.688^{*}$ & $-0.803 * *$ & $-0.736 * *$ & $-0.679 *$ & $-0.794 * *$ \\
\hline SAVI2 & $0.468^{\mathrm{NS}}$ & $-0.381^{\mathrm{NS}}$ & $0.025^{\mathrm{NS}}$ & $0.538^{\mathrm{NS}}$ & $-0.395^{\mathrm{NS}}$ & $-0.040^{\mathrm{NS}}$ \\
\hline SAVI & $0.751 * *$ & $0.635^{*}$ & $0.708^{* *}$ & $0.687^{*}$ & $0.629 *$ & $0.772 * *$ \\
\hline TSAVI & $0.760 * *$ & $0.638^{*}$ & $0.725^{* *}$ & $0.706^{*}$ & $0.622 *$ & $0.786 * *$ \\
\hline TVI & $0.701^{*}$ & $0.567^{\mathrm{NS}}$ & $0.763^{* *}$ & $0.624 *$ & $0.582^{*}$ & $0.733 * *$ \\
\hline VOG & $0.844 * *$ & $0.833^{*} *$ & $0.832^{* *}$ & $0.801 * *$ & $0.784 * *$ & $0.785 * *$ \\
\hline VOG2 & $-0.857 * *$ & $-0.877 * *$ & $-0.852 * *$ & $-0.812 * *$ & $-0.822 * *$ & $-0.806 * *$ \\
\hline WBI & $0.776 * *$ & $0.821 * *$ & $0.813^{* *}$ & $0.719 * *$ & $0.765^{* *}$ & $0.683 *$ \\
\hline ZMI & $0.836 * *$ & $0.803^{* *}$ & $0.848 * *$ & $0.792 * *$ & $0.764 * *$ & $0.780 * *$ \\
\hline
\end{tabular}

*Significant at $P \leq 0.05 ; * *$ Significant at $P \leq 0.01$; NS, Not significantly different.
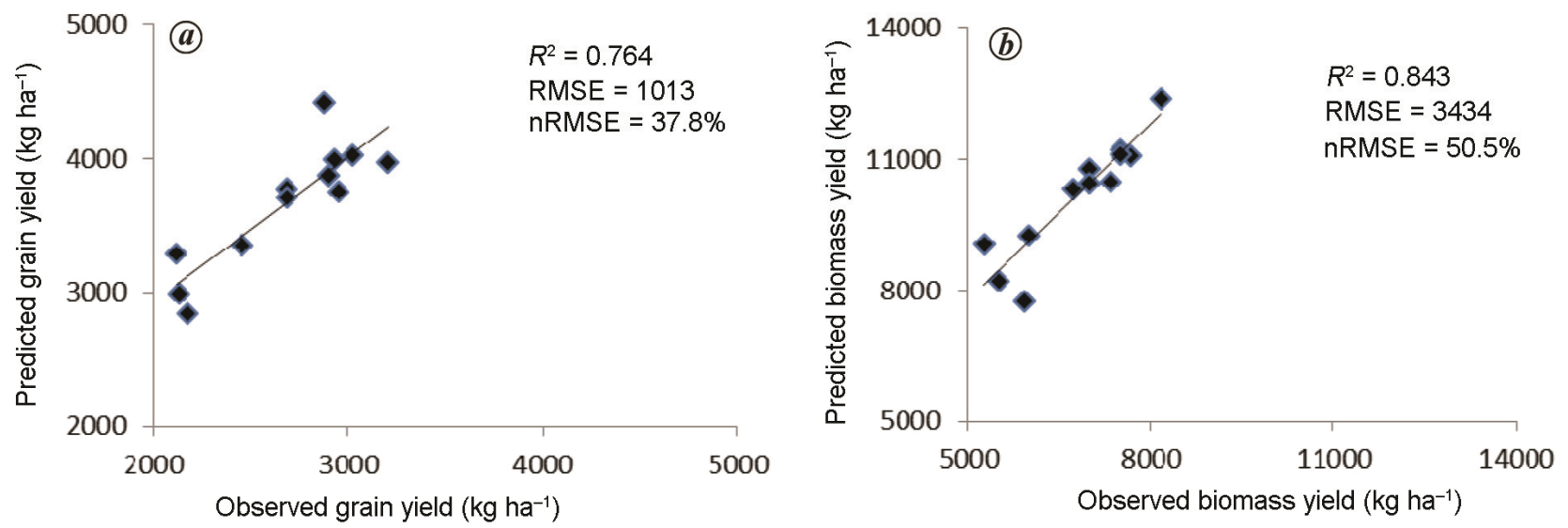

Figure 3. Validation of normalized difference red edge index-based regression model for prediction of $(\boldsymbol{a})$ grain and $(\boldsymbol{b})$ biomass yield of wheat. 
RESEARCH ARTICLES

Table 5. Structural hyperspectral indices as influenced by tillage, residue and nitrogen management in 2016-17

\begin{tabular}{|c|c|c|c|c|c|c|c|}
\hline Index & $\mathrm{CT}$ & NT & R0 & $\mathrm{R}+$ & N60 & N120 & N180 \\
\hline GMI & $4.12^{\mathrm{A} \#}$ & $3.84^{\mathrm{A}}$ & $3.84^{\mathrm{A}}$ & $4.11^{\mathrm{A}}$ & $3.08^{\mathrm{B}}$ & $4.31^{\mathrm{A}}$ & $4.56^{\mathrm{A}}$ \\
\hline mND_705 & $1.51^{\mathrm{A}}$ & $1.35^{\mathrm{A}}$ & $1.36^{\mathrm{A}}$ & $1.50^{\mathrm{A}}$ & $1.01^{\mathrm{B}}$ & $1.58^{\mathrm{A}}$ & $1.70^{\mathrm{A}}$ \\
\hline MREN̄NDI & $0.60^{\mathrm{A}}$ & $0.57^{\mathrm{A}}$ & $0.57^{\mathrm{A}}$ & $0.60^{\mathrm{A}}$ & $0.51^{\mathrm{B}}$ & $0.63^{\mathrm{A}}$ & $0.63^{\mathrm{A}}$ \\
\hline MRESR & $4.13^{\mathrm{A}}$ & $3.87^{\mathrm{A}}$ & $3.88^{\mathrm{A}}$ & $4.11^{\mathrm{A}}$ & $3.17^{\mathrm{B}}$ & $4.48^{\mathrm{A}}$ & $4.35^{\mathrm{A}}$ \\
\hline NDREI & $0.33^{\mathrm{A}}$ & $0.31^{\mathrm{A}}$ & $0.31^{\mathrm{A}}$ & $0.33^{\mathrm{A}}$ & $0.26^{\mathrm{B}}$ & $0.35^{\mathrm{A}}$ & $0.35^{\mathrm{A}}$ \\
\hline NDVI & $0.82^{\mathrm{A}}$ & $0.77^{\mathrm{A}}$ & $0.79^{\mathrm{A}}$ & $0.80^{\mathrm{A}}$ & $0.72^{\mathrm{B}}$ & $0.82^{\mathrm{A}}$ & $0.84^{\mathrm{A}}$ \\
\hline PVI & $-0.002^{\mathrm{A}}$ & $-0.005^{\mathrm{A}}$ & $-0.004^{\mathrm{A}}$ & $-0.003^{\mathrm{A}}$ & $-0.009^{\mathrm{B}}$ & $-0.001^{\mathrm{A}}$ & $-0.001^{\mathrm{A}}$ \\
\hline RI_1dB & $1.55^{\mathrm{A}}$ & $1.49^{\mathrm{A}}$ & $1.50^{\mathrm{A}}$ & $1.54^{\mathrm{A}}$ & $1.40^{\mathrm{B}}$ & $1.57^{\mathrm{A}}$ & $1.59^{\mathrm{A}}$ \\
\hline RI_2dB & $1.64^{\mathrm{A}}$ & $1.58^{\mathrm{A}}$ & $1.59^{\mathrm{A}}$ & $1.63^{\mathrm{A}}$ & $1.46^{\mathrm{B}}$ & $1.67^{\mathrm{A}}$ & $1.69^{\mathrm{A}}$ \\
\hline RI_Half & $2.87^{\mathrm{A}}$ & $2.69^{\mathrm{A}}$ & $2.71^{\mathrm{A}}$ & $2.86^{\mathrm{A}}$ & $2.29^{\mathrm{B}}$ & $3.08^{\mathrm{A}}$ & $2.98^{\mathrm{A}}$ \\
\hline RENDVI & $0.53^{\mathrm{A}}$ & $0.49^{\mathrm{A}}$ & $0.50^{\mathrm{A}}$ & $0.52^{\mathrm{A}}$ & $0.43^{\mathrm{B}}$ & $0.56^{\mathrm{A}}$ & $0.55^{\mathrm{A}}$ \\
\hline VOG & $1.69^{\mathrm{A}}$ & $1.63^{\mathrm{A}}$ & $1.64^{\mathrm{A}}$ & $1.68^{\mathrm{A}}$ & $1.50^{\mathrm{B}}$ & $1.75^{\mathrm{A}}$ & $1.73^{\mathrm{A}}$ \\
\hline ZMI & $2.72^{\mathrm{A}}$ & $2.55^{\mathrm{A}}$ & $2.57^{\mathrm{A}}$ & $2.70^{\mathrm{A}}$ & $2.19^{\mathrm{B}}$ & $2.82^{\mathrm{A}}$ & $2.90^{\mathrm{A}}$ \\
\hline
\end{tabular}

"Values in a column followed by the same letters are not significantly different at $P<0.05$ according to DMRT.

Table 6. Structural hyperspectral indices as influenced by tillage, residue and nitrogen management in 2017-18

\begin{tabular}{|c|c|c|c|c|c|c|c|}
\hline Index & CT & NT & R0 & $\mathrm{R}+$ & N60 & N120 & N180 \\
\hline GMI & $4.98^{\mathrm{A}}$ & $5.19^{\mathrm{A}}$ & $5.41^{\mathrm{A}}$ & $4.77^{\mathrm{A}}$ & $3.58^{\mathrm{C}}$ & $5.30^{\mathrm{B}}$ & $6.39^{\mathrm{A}}$ \\
\hline mND_705 & $1.95^{\mathrm{A}}$ & $1.99^{\mathrm{A}}$ & $2.11^{\mathrm{A}}$ & $1.82^{\mathrm{A}}$ & $1.28^{\mathrm{C}}$ & $2.06^{\mathrm{B}}$ & $2.56^{\mathrm{A}}$ \\
\hline MREN̄NDI & $0.64^{\mathrm{A}}$ & $0.64^{\mathrm{A}}$ & $0.65^{\mathrm{A}}$ & $0.63^{\mathrm{A}}$ & $0.56^{\mathrm{C}}$ & $0.67^{\mathrm{B}}$ & $0.70^{\mathrm{A}}$ \\
\hline MRESR & $4.72^{\mathrm{A}}$ & $4.95^{\mathrm{A}}$ & $5.04^{\mathrm{A}}$ & $4.63^{B}$ & $3.57^{\mathrm{C}}$ & $5.06^{\mathrm{B}}$ & $5.87^{\mathrm{A}}$ \\
\hline NDREI & $0.36^{\mathrm{A}}$ & $0.37^{\mathrm{A}}$ & $0.37^{\mathrm{A}}$ & $0.36^{\mathrm{A}}$ & $0.29^{\mathrm{C}}$ & $0.38^{\mathrm{B}}$ & $0.42^{\mathrm{A}}$ \\
\hline NDVI & $0.86^{\mathrm{A}}$ & $0.85^{\mathrm{A}}$ & $0.87^{\mathrm{A}}$ & $0.84^{\mathrm{A}}$ & $0.77^{\mathrm{B}}$ & $0.88^{\mathrm{A}}$ & $0.91^{\mathrm{A}}$ \\
\hline PVI & $0.003^{\mathrm{A}}$ & $0.001^{\mathrm{A}}$ & $0.003^{\mathrm{A}}$ & $0.002^{\mathrm{A}}$ & $-0.005^{\mathrm{C}}$ & $0.003^{\mathrm{B}}$ & $0.009^{\mathrm{A}}$ \\
\hline RI_1dB & $1.55^{\mathrm{A}}$ & $1.56^{\mathrm{A}}$ & $1.57^{\mathrm{A}}$ & $1.53^{\mathrm{A}}$ & $1.42^{\mathrm{C}}$ & $1.58^{\mathrm{B}}$ & $1.66^{\mathrm{A}}$ \\
\hline RI_2dB & $1.65^{\mathrm{A}}$ & $1.66^{\mathrm{A}}$ & $1.68^{\mathrm{A}}$ & $1.63^{\mathrm{B}}$ & $1.49^{\mathrm{C}}$ & $1.69^{\mathrm{B}}$ & $1.78^{\mathrm{A}}$ \\
\hline RI_Half & $3.20^{\mathrm{A}}$ & $3.28^{\mathrm{A}}$ & $3.37^{\mathrm{A}}$ & $3.11^{\mathrm{B}}$ & $2.53^{\mathrm{C}}$ & $3.36^{\mathrm{B}}$ & $3.83^{\mathrm{A}}$ \\
\hline RENDVI & $0.58^{\mathrm{A}}$ & $0.58^{\mathrm{A}}$ & $0.59^{\mathrm{A}}$ & $0.56^{\mathrm{A}}$ & $0.49^{\mathrm{C}}$ & $0.60^{\mathrm{B}}$ & $0.65^{\mathrm{A}}$ \\
\hline VOG & $1.71^{\mathrm{A}}$ & $1.72^{\mathrm{A}}$ & $1.75^{\mathrm{A}}$ & $1.69^{\mathrm{B}}$ & $1.54^{\mathrm{C}}$ & $1.75^{\mathrm{B}}$ & $1.87^{\mathrm{A}}$ \\
\hline ZMI & $3.01^{\mathrm{A}}$ & $3.07^{\mathrm{A}}$ & $3.15^{\mathrm{A}}$ & $2.93^{\mathrm{B}}$ & $2.41^{\mathrm{C}}$ & $3.15^{\mathrm{B}}$ & $3.57^{\mathrm{A}}$ \\
\hline
\end{tabular}

"Values in a column followed by the same letters are not significantly different at $P<0.05$ according to DMRT.

maximum $76 \%$ variation in the observed grain yield (Figure $3 a$ ) with RMSE and nRMSE of $1013 \mathrm{~kg} / \mathrm{ha}$ and $37.8 \%$ respectively.

The regression models between selected 10 SRI and aboveground biomass accounted for $52-66 \%$ variation in the biomass yield of wheat for 2016-17 (Table 7). The independent datasets of aboveground biomass and SRI recorded at booting stage in 2017-18 were used to validate these regression models (Table 9). It was observed that the regression models could account for $65-84 \%$ variation in the aboveground biomass of wheat during validation. Out of the 10 SRI-based regression models, the NDREI-based model could account for maximum $84 \%$ variation in the observed aboveground biomass yield (Figure $3 b$ ) with RMSE and nRMSE of $3434 \mathrm{~kg} \mathrm{ha}^{-1}$ and $50.5 \%$ respectively. The validation result showed overestimation of grain and biomass yield by all the models.

\section{Discussion}

\section{Grain and biomass yield of wheat}

There was a decrease in grain and biomass yield by $23.6 \%$ and $34.2 \%$ during 2017-18 compared to 2016-17.
This was mainly attributed to lower rainfall received in 2017-18 and higher maximum temperature experienced by the crop during January-March of 2017-18 compared to 2016-17. The low rainfall and high temperature stress was found to limit the growth of wheat crop during 2017 18 compared to 2016-17. This finding is in agreement with that of Rani et al. ${ }^{35}$. Grain and aboveground biomass yield of wheat were not significantly affected by the tillage treatments. This may be due to the fact that the experiment was of short duration (3 years) and hence favourable changes in soil physical environment due to no tillage are yet to be achieved. This finding shows that excessive tillage under CT can be avoided without significant reduction in wheat yield. It will save fossil-fuel consumption and improve soil health under no tillage in this soil and agroclimatic condition. This finding is in agreement with those of Rani et al. ${ }^{35}$ and Mohammad et $a l{ }^{36}$. Wheat grain and aboveground biomass yield were also not significantly affected by residue mulch treatment. However, the grain and aboveground biomass yield of wheat increased significantly $(P \leq 0.05)$ with increase in $\mathrm{N}$ levels (Table 2). Among all the essential nutrients required for the plants, $\mathrm{N}$ is the major one, which has a key role in the process of photosynthesis. Increased rate of 
Table 7. Regression models between selected hyperspectral indices and grain and biomass yield of wheat in 2016-17 across different tillage, residue and nitrogen management practices

\begin{tabular}{|c|c|c|c|c|}
\hline \multirow[b]{2}{*}{ Index } & \multicolumn{2}{|c|}{ Grain yield } & \multicolumn{2}{|l|}{ Biomass yield } \\
\hline & Relationship & $R^{2}$ & Relationship & $R^{2}$ \\
\hline GMI & $y=501.4 x+1313$ & 0.653 & - & - \\
\hline mND_705 & $y=1045 x+1812$ & 0.642 & - & - \\
\hline MRENDVI & $y=5855 x-127.7$ & 0.727 & $y=17273 x-1011$ & 0.664 \\
\hline MRESR & $y=588.5 x+955.8$ & 0.721 & $y=1732 x+2199$ & 0.656 \\
\hline NDREI & $y=7690 x+855.4$ & 0.728 & $y=22639 x+1904$ & 0.662 \\
\hline NDVI & $y=4882 x-574.1$ & 0.589 & $y=14105 x-2090$ & 0.516 \\
\hline PVI & $y=84026 x+3587$ & 0.708 & - & - \\
\hline RI_1dB & $y=3887 x-2599$ & 0.708 & $y=11343 x-8114$ & 0.633 \\
\hline RI_2dB & $y=3225 x-1873$ & 0.706 & $y=9428 x-6025$ & 0.633 \\
\hline RI_Half & $y=950.6 x+665.8$ & 0.691 & - & - \\
\hline RENDVI & $y=5332 x+588.5$ & 0.694 & $y=15673 x+1131$ & 0.629 \\
\hline VOG & $y=2939 x-1569$ & 0.712 & $y=8606 x-5154$ & 0.641 \\
\hline VOG2 & - & - & $y=-33064 x+4188$ & 0.659 \\
\hline ZMI & $y=1046 x+550.0$ & 0.698 & $y=3059 x+1059$ & 0.626 \\
\hline
\end{tabular}

Table 8. Validation of regression models for prediction of grain yield of wheat in 2017-18 under different tillage, residue and nitrogen management practices

\begin{tabular}{|c|c|c|c|c|c|c|}
\hline Index & $\begin{array}{l}\text { Mean observed grain } \\
\text { yield }\left(\mathrm{kg} \mathrm{ha}^{-1}\right)\end{array}$ & $\begin{array}{l}\text { Mean predicted grain } \\
\text { yield }\left(\mathrm{kg} \mathrm{ha}^{-1}\right)\end{array}$ & $\begin{array}{l}\text { Mean prediction } \\
\text { error }(\%)\end{array}$ & $R^{2}$ & $\begin{array}{l}\text { RMSE } \\
\left(\mathrm{kg} \mathrm{ha}^{-1}\right)\end{array}$ & $\begin{array}{l}\text { nRMSE } \\
(\%)\end{array}$ \\
\hline GMI & 2678 & 3864 & -44.32 & 0.591 & 1274 & 47.6 \\
\hline mND_705 & 2678 & 3866 & -44.38 & 0.611 & 1263 & 47.2 \\
\hline MREÑNVI & 2678 & 3631 & -35.61 & 0.728 & 976 & 36.4 \\
\hline MRESR & 2678 & 3800 & -41.92 & 0.647 & 1191 & 44.5 \\
\hline NDREI & 2678 & 3667 & -36.95 & 0.764 & 1013 & 37.8 \\
\hline NDVI & 2678 & 3582 & -33.79 & 0.664 & 931 & 34.8 \\
\hline PVI & 2678 & 3785 & -41.37 & 0.695 & 1164 & 43.5 \\
\hline $\mathrm{RI}_{1 \mathrm{~dB}}$ & 2678 & 3438 & -28.40 & 0.709 & 794 & 29.7 \\
\hline $\mathrm{R} 1_{2 \mathrm{~dB}}$ & 2678 & 3462 & -29.30 & 0.71 & 818 & 30.5 \\
\hline $\mathrm{RI}_{\text {half }}$ & 2678 & 3747 & -39.93 & 0.654 & 1127 & 42.1 \\
\hline RENDVI & 2678 & 3661 & -36.71 & 0.722 & 1006 & 37.6 \\
\hline VOG & 2678 & 3480 & -29.97 & 0.711 & 836 & 31.2 \\
\hline ZMI & 2678 & 3732 & -39.37 & 0.667 & 1108 & 41.4 \\
\hline
\end{tabular}

photosynthesis with increase in $\mathrm{N}$ leads to greater yields because of large amounts of dry matter accumulation, and more assimilates produced and transported to fill the grains as a result of more applied nitrogen. Ullah et al. ${ }^{37}$ reported that the grain yield of wheat increased with increase in applied N. The increase in grain and biomass yield with increase in applied $\mathrm{N}$ might also have resulted from increased leaf area index (LAI), green spikes area and crop duration with greenness, which resulted in increased capture of radiation. These results are in agreement with those of earlier studies ${ }^{19,38,39}$.

\section{Effect of tillage, residue mulch and nitrogen on canopy reflectance spectra}

It was observed that canopy reflectance spectra were not significantly influenced due to tillage and residue management throughout the spectral region. As already discussed, there was no significant effect of tillage and residue on biomass yield in this short-term study, which was reflected in the canopy spectra. Similar finding has also been reported by Pradhan et al. ${ }^{19}$. However, Zhao et $a l .{ }^{31}$ reported that changing the background from soil to residue resulted in substantial changes in both reflectance and vegetation indices of canopies when LAI varied between 0.1 and 1.0. Since spectral reflectance was recorded at booting stage, when the LAI was more than 1.0, the effect of crop residue mulch on spectral reflectance was not found to be significant. The canopy reflectance of wheat at booting stage showed significant difference due to $\mathrm{N}$ levels throughout the wavelength (350 to $1800 \mathrm{~nm}$ ) of spectral reflectance measurement. The canopy reflectance in the visible region (400-700 nm) was highest for N60 treatment followed by N120 and N180 treatments. This could be attributed to lower green biomass and lower total chlorophyll content in N60 treatment compared to $\mathrm{N} 120$ and N180 treatments ${ }^{40,41}$. A reduction in $\mathrm{N}$ application would reduce chlorophyll pigment concentration, which will result in decreased absorption and increased reflection in the visible region at 450 and $680 \mathrm{~nm}$ (ref. 42). However, N180 treatment showed highest reflectance in the NIR region followed by N120 and 


\section{RESEARCH ARTICLES}

Table 9. Validation of regression models for prediction of biomass yield of wheat in 2017-18 under different tillage, residue and nitrogen management practices

\begin{tabular}{|c|c|c|c|c|c|c|}
\hline Index & $\begin{array}{c}\text { Mean observed biomass } \\
\text { yield }\left(\mathrm{kg} \mathrm{ha}^{-1}\right)\end{array}$ & $\begin{array}{c}\text { Mean predicted biomass } \\
\text { yield }\left(\mathrm{kg} \mathrm{ha}^{-1}\right)\end{array}$ & $\begin{array}{l}\text { Mean prediction } \\
\text { error }(\%)\end{array}$ & $R^{2}$ & $\begin{array}{l}\text { RMSE } \\
\left(\mathrm{kg} \mathrm{ha}^{-1}\right)\end{array}$ & $\begin{array}{l}\text { nRMSE } \\
(\%)\end{array}$ \\
\hline MRENDVI & 6800 & 10078 & -48.21 & 0.795 & 3325 & 48.9 \\
\hline MRESR & 6800 & 10570 & -55.44 & 0.832 & 3924 & 57.7 \\
\hline NDREI & 6800 & 10182 & -49.73 & 0.843 & 3434 & 50.5 \\
\hline NDVI & 6800 & 9919 & -45.86 & 0.652 & 3178 & 46.7 \\
\hline $\mathrm{RI}_{1 \mathrm{~dB}}$ & 6800 & 9572 & -40.77 & 0.831 & 2831 & 41.6 \\
\hline $\mathrm{RI}_{2 \mathrm{~dB}}$ & 6800 & 9631 & -41.63 & 0.833 & 2892 & 42.5 \\
\hline RENDVI & 6800 & 10518 & -54.67 & 0.85 & 3802 & 55.9 \\
\hline VOG & 6800 & 10161 & -49.43 & 0.782 & 3411 & 50.2 \\
\hline VOG2 & 6800 & 10161 & -49.43 & 0.782 & 3411 & 50.2 \\
\hline ZMI & 6800 & 10364 & -52.41 & 0.826 & 3682 & 54.1 \\
\hline
\end{tabular}

N60 treatments. This is attributed to the lower leaf area index in N60 and N120 treatments compared to N180 treatment. Canopy reflectance in the NIR region is directly related to leaf area and biomass, which increase with the increase in applied $\mathrm{N}^{41,43,44}$.

\section{Prediction of grain and biomass yield}

This study shows that most of the spectral indices at booting stage have higher correlation with both the grain and biomass yield among the three stages. Similar results were reported by Pradhan et al. ${ }^{19}$. Ranjan et $a l .{ }^{45}$ also reported that spectral reflectance pattern of wheat crop at booting stage was most distinct for varying $\mathrm{N}$ stress levels. In this study, regression models were developed between selected hyperspectral indices $(r \geq 0.802)$ at booting stage and grain and biomass yield of 2016-17. These models were validated with the spectral indices of 2017-18. The validation result showed overestimation of grain and biomass yield by all the models. This was attributed to the reduction in the grain and biomass yield during 2017-18 due to low rainfall and high temperature compared to 2016-17. Validation results showed that NDREI-based regression model could account for maximum $76.4 \%$ variation in the observed grain yield and $84.3 \%$ variation in the observed biomass yield. In this study, the variation of yield is mainly due to different $\mathrm{N}$ doses. This variation may be accounted by NDREI, which is sensitive to the chlorophyll and $\mathrm{N}$ content of the canopy. Derivative-based red-edge indices were reported to be more sensitive to changes in both leaf chlorophyll content and LAI at dense plant canopy or biomass ${ }^{46,47}$. The red edge $(660-780 \mathrm{~nm})$ was reported to be effective and accurate in estimating grain yield of wheat ${ }^{48}$. Kanke et $a l .^{49}$ also reported a linear relationship between NDREI and rice grain and biomass yield.

\section{Conclusion}

The grain and biomass yield of wheat were not significantly influenced by the tillage and residue management, but increased significantly with increase in $\mathrm{N}$ levels. The canopy reflectance also showed similar pattern, i.e. it was not significantly affected by different tillage and residue management practices. However, it was significantly influenced by different $\mathrm{N}$ treatments throughout the spectral region. Most of the hyperspectral indices at the booting stage were found to have higher correlation with grain and biomass yield of wheat compared to other stages. From the analysis of the quantitative relationships between grain and biomass yield and various hyperspectral indices, regression models based on NDREI were found to be the best for the prediction of both grain and biomass yield of wheat. Thus it may be concluded that the regression models based on NDREI at booting stage can be used to predict grain yield and above-ground biomass of wheat in advance.

1. Rashidi, M. and Keshavarzpour, F., Effect of different tillage methods on soil physical properties and crop yield of watermelon (Citrullus vulgaris). ARPN J. Agric. Biol. Sci., 2007, 2(6), 1-16.

2. Kumar, S. et al., Long-term tillage and drainage influences on soil organic carbon dynamics, aggregate stability and corn yield. J. Soil Sci. Plant Nutr., 2014, 60(1), 108-118.

3. Ogban, P. I., Ogunewe, W. N., Dike, R. I., Ajaelo, A. C., Ikeata, N. I., Achumba, U. E. and Nyong, E. E., Effect of tillage and mulching practices on soil properties and growth and yield of cowpea (Vigna unguiculata (L), Walp) in Southeastern Nigeria. J. Trop. Agric., Food, Environ. Extension, 2008, 7(2), 118-128.

4. Anikwe, M. A. N. and Ubochi, J. N., Short-term changes in soil properties under tillage systems and their effect on sweet potato (Ipomea batatas L.) growth and yield in an Ultisol in southeastern Nigeria. Soil Res., 2007, 45(5), 351-358.

5. Boone, F. R. and Veen, B. W., Mechanisms of crop responses to soil compaction. Developments in Agricultural Engineering, Elsevier, 1994, vol. 11, pp. 237-264.

6. Davis, J. G., Managing plant nutrients for optimum water use efficiency and water conservation. Adv. Agro, 1994, 53, 85-121.

7. Lal, R., Tillage effects on soil degradation, soil resilience, soil quality, and sustainability. Soil Tillage Res., 1993, 27(1-4), 1-8.

8. Acharya, C. L., Hati, K. M. and Bandyopadhyay, K. K., Mulches In Encyclopedia of Soils in the Environment (eds Hillel, D. et al.), Elsevier Publication, 2005, pp. 521-532.

9. Chandel, N. S., Tiwari, P. S., Singh, K. P., Jat, D., Gaikwad, B. B., Tripathi, H. and Golhani, K., Yield prediction in wheat (Triticum aestivum L.) using spectral reflectance indices. Curr. Sci., 2019, 116(2), 272. 
10. Royo, C., Aparicio, N., Villegas, D., Casadesus, J., Monneveux, P. and Araus, J. L., Usefulness of spectral reflectance indices as durum wheat yield predictors under contrasting Mediterranean conditions. Int. J. Remote Sensing, 2003, 24(22), 4403-4419.

11. Babar, M. A., Reynolds, M. P., Van Ginkel, M., Klatt, A. R., Raun, W. R. and Stone, M. L., Spectral reflectance indices as a potential indirect selection criteria for wheat yield under irrigation. Crop Sci., 2006, 46(2), 578-588.

12. Prasad, B., Carver, B. F., Stone, M. L., Babar, M. A., Raun, W. R. and Klatt, A. R., Potential use of spectral reflectance indices as a selection tool for grain yield in winter wheat under Great Plains conditions. Crop Sci., 2007, 47(4), 1426-1440.

13. Li-Hong, X. U. E., Wei-Xing, C. A. O. and Lin-Zhang, Y. A. N. G., Predicting grain yield and protein content in winter wheat at different $\mathrm{N}$ supply levels using canopy reflectance spectra. Pedosphere, 2007, 17(5), 646-653.

14. Araus, J., Slafer, G. A., Reynolds, M. P. and Royo, C., Plant breeding and drought in $\mathrm{C}_{3}$ cereals: what should we breed for? Ann. Bot., 2002, 89(7), 925-940.

15. Raun, W. R., Solie, J. B., Johnson, G. V., Stone, M. L., Lukina, E. V., Thomason, W. E. and Schepers, J. S., In-season prediction of potential grain yield in winter wheat using canopy reflectance. Agron. J., 2001, 93(1), 131-138.

16. Serrano, L., Filella, I. and Penuelas, J., Remote sensing of biomass and yield of winter wheat under different nitrogen supplies. Crop Sci., 2000, 40(3), 723-731.

17. Aparicio, N., Villegas, D., Casadesus, J., Araus, J. L. and Royo, C., Spectral vegetation indices as nondestructive tools for determining durum wheat yield. Agron. J., 2000, 92(1), 83-91.

18. Dempewolf, J., Becker-Reshef, I., Adusei, B. and Barker, B., Performance of vegetation indices for wheat yield forecasting for Punjab, Pakistan. In AGU Fall Meeting Abstracts, 2013.

19. Pradhan, S., Bandyopadhyay, K. K., Sahoo, R. N., Sehgal, V. K., Singh, R., Gupta, V. K. and Joshi, D. K., Predicting wheat grain and biomass yield using canopy reflectance of booting stage. J. Indian Soc. Remote. Sensing, 2014, 42(4), 711-718.

20. Bandyopadhyay, K. K., Pradhan, S., Sahoo, R. N., Singh, R., Gupta, V. K., Joshi, D. K. and Sutradhar, A. K., Characterization of water stress and prediction of yield of wheat using spectral indices under varied water and nitrogen management practices. Agric. Water Manage., 2014, 146, 115-123.

21. Lawrence, R. L. and Ripple, W. J., Comparisons among vegetation indices and band wise regression in a highly disturbed, heterogeneous landscape: Mount St. Helens, Washington. Remote Sensing Environ, 1998, 64(1), 91-102.

22. Shibayama, M. and Akiyama, T., Estimating grain yield of maturing rice canopies using high spectral resolution reflectance measurements. Remote Sensing Environ., 1991, 36, 45-53.

23. Daughtry, C. S. T., Discriminating crop residues from soil by shortwave infrared reflectance. Agron. J., 2001, 93, 125-131.

24. Daughtry, C. and Hunt Jr, E., Mitigating the effects of soil and residue water contents on remotely sensed estimates of crop residue cover. Remote Sensing Environ., 2008, 112, 1647-1657.

25. Pearson, R. L. and Miller, L. D., Remote mapping of standing crop biomass for estimation of the productivity of the short-grass Prairie, Pawnee National Grasslands, Colorado. In Proceedings of the 8th International Symposium on Remote Sensing of Environment, ERIM, Ann Arbor, MI, 1972, pp. 1357-1381.

26. Rouse, J. W., Haas, R. H., Schell, J. A., Deering, D. W. and Harlan, J. C., Monitoring the vernal advancement of retrogradation of natural vegetation. NASA/GSFC, Type III, Final Report, Greenbelt, MD, USA, 1974, pp. 1-371.

27. Baret, F., Guyot, G. and Major, D. J., TASVI: a vegetation index which minimizes soil brightness effects on LAI and APAR estimation. In Proceedings of IGARSS' 89 and 12th Canadian Symposium on Remote Sensing, Vancouver, Canada, 10-14 July 1989, pp. $1355-1358$.
28. Major, D., Baret, F. and Guyot, G., A ratio vegetation index adjusted for soil brightness. Int. J. Remote Sensing, 1990, 11, 727-740.

29. Zhao, D., Huang, L., Li, J. and Qi, J., A comparative analysis of broadband and narrowband derived vegetation indices in predicting LAI and CCD of a cotton canopy. ISPRS J. Photogramm. Remote Sensing, 2007, 62, 25-33.

30. Yao, X., Zhu, Y., Tian, Y. C., Feng, W. and Cao, W. X., Exploring hyperspectral bands and estimation indices for leaf nitrogen accumulation in wheat. Int. J. Appl. Earth Obs. Geoinf., 2010, 12, 89-100.

31. Zhao, D., Yang, T. and An, S., Effects of crop residue cover resulting from tillage practices on LAI estimation of wheat canopies using remote sensing. Int. J. Appl. Earth Obs. Geoinf., 2011, 14(1), 169-177.

32. Eskandari, I., Navid, H. and Rangzan, K., Evaluating spectral indices for determining conservation and conventional tillage systems in a vetch-wheat rotation. Int. Soil Water Conserv. Res., 2016, 4(2), 93-98.

33. Savitzky, A. and Golay, M. J. E., Smoothing and differentiation of data by simplified least squares procedures. Anal. Chem., 1964, 36, 1627-1638.

34. Gomez, K. A. and Gomez, A. A., Statistical Procedures for Agricultural Research, John Wiley \& Sons, 1984.

35. Rani, A., Bandyopadhyay, K. K., Krishnan, P., Sarangi, A. and Datta, S., Effect of tillage, residue and nitrogen management on soil physical properties, soil temperature dynamics and yield of wheat in an inceptisol. J. Agric. Phys., 2017, 17(1), 31-44.

36. Mohammad, W., Shah, S. M., Shehzadi, S. and Shah, S. A., Effect of tillage, rotation and crop residues on wheat crop productivity, fertilizer nitrogen and water use efficiency and soil organic carbon status in dry area (rainfed) of north-west Pakistan. J. Soil Sci. Plant Nutr., 2012, 12(4), 715-727.

37. Ullah, I. et al., Effect of different nitrogen levels on growth, yield and yield contributing attributes of wheat. Int. J. Sci. Eng. Res., 2018, 9, 595-602.

38. López-Bellido, L., Fuentes, M., Castillo, J. E. and López-Garrido, F. J., Effects of tillage, crop rotation and nitrogen fertilization on wheat-grain quality grown under rainfed Mediterranean conditions. Field Crops Res., 1998, 57(3), 265-276.

39. Bandyopadhyay, P. K., Singh, K. C., Mondal, K., Nath, R., Kumar, N. and Singh, S. S., Effect of balanced fertilization in puddled rice on the productivity of lentil in rice-fallow system under zero tillage. Bangladesh Agron. J., 2016, 19(1), 67-79.

40. Lee, Y. J., Yang, C. M. and Chang, A. H., Changes of nitrogen and chlorophyll contents and reflectance spectral characteristics to the application of nitrogen fertilizer in rice plants. J. Agric. Res. China, 2002, 51(1), 1-14.

41. Chang, K. W., Shen, Y. and Lo, J. C., Predicting rice yield using canopy reflectance measured at booting stage. Agron. J., 2005, 97(3), 872-878.

42. Joseph, G., Fundamentals of Remote Sensing, Universities Press (India) Private Limited, Hyderabad, AP, India, 2005.

43. Guyot G., Optical properties of vegetation canopies. Optical Properties of Vegetation Canopies, 1990, 19-43.

44. Asner, G. P., Biophysical and biochemical sources of variability in canopy reflectance. Remote Sensing Environ., 1998, 64(3), 234253.

45. Ranjan, R., Chopra, U. K., Sahoo, R. N., Singh, A. K. and Pradhan, S., Assessment of plant nitrogen stress in wheat (Triticum aestivum L.) through hyperspectral indices. Int. J. Remote Sensing, 2012, 33(20), 6342-6360.

46. $\mathrm{Pu}, \mathrm{R}$., Gong, P., Biging, G. S. and Larrieu, M. R., Extraction of red edge optical parameters from hyperion data for estimation of forest leaf area index. IEEE Trans. Geosci. Remote Sensing, 2003, 41, 916-921.

47. Cho, M. A., Skidmore, A. K. and Atzberger, C., Towards red-edge positions less sensitive to canopy biophysical parameters for leaf 
chlorophyll estimation using properties optiquespectrales des feuilles (PROSPECT) and scattering by arbitratily inclined leaves (SAILH) simulated data. Int. J. Remote Sensing, 2008, 29, 22412255.

48. Sharabian, V. R., Noguchi, N. and Ishi, K., Significant wavelengths for prediction of winter wheat growth status and grain yield using multivariate analysis. Eng. Agric., Environ. Food, 2014, 7(1), 14-21.

49. Kanke, Y., Tubana, B., Dalen, M. and Harrell, D., Evaluation of red and red-edge reflectance-based vegetation indices for rice biomass and grain yield prediction models in paddy fields. Precis. Agric., 2016, 17(5), 507-530.

50. Carter, G. A., Ratios of leaf reflectances in narrow wavebands as indicators of plant stress. Remote Sensing, 1994, 15(3), 697-703.

51. Zarco-Tejada, P. J. et al., Assessing vineyard condition with hyperspectral indices: Leaf and canopy reflectance simulation in a row-structured discontinuous canopy. Remote Sensing Environ., 2005, 99(3), 271-287.

52. Gitelson, A. A. and Merzlyak, M. N., Remote estimation of chlorophyll content in higher plant leaves. Int. J. Remote Sensing, 1997, 18(12), 2691-2697.

53. Kauth, R. J. and Thomas, G. S., The tasselled cap a graphic description of the spectral-temporal development of agricultural crops as seen by Landsat. In LARS Symposia, 1976, p. 159.

54. Lichtenthaler, H. K., Gitelson, A. and Lang, M., Non-destructive determination of chlorophyll content of leaves of a green and an aurea mutant of tobacco by reflectance measurements. J. Plant Physiol., 1996, 148(3-4), 483-493.

55. Sims, D. A. and Gamon, J. A., Relationships between leaf pigment content and spectral reflectance across a wide range of species, leaf structures and developmental stages. Remote Sensing Environ., 2002, 81(2-3), 337-354.

56. Datt, B., Visible/near infrared reflectance and chlorophyll content in Eucalyptus leaves. Int. J. Remote Sensing, 1999, 20(14), 2741-2759.

57. Chen, J. M., Evaluation of vegetation indices and a modified simple ratio for boreal applications. Can. J. Remote Sensing, 1996, 22(3), 229-242.

58. Qi, J., Chehbouni, A., Huete, A. R., Kerr, Y. H. and Sorooshian, S., A modified soil adjusted vegetation index. Remote Sensing Environ., 1994, 48(2), 119-126.

59. Haboudane, D., Miller, J. R., Pattey, E., Zarco-Tejada, P. J. and Strachan, I. B., Hyperspectral vegetation indices and novel algorithms for predicting green LAI of crop canopies: Modeling and validation in the context of precision agriculture. Remote Sensing Environ., 2004, 90(3), 337-352.

60. Rodriguez, D., Fitzgerald, G. J., Belford, R. and Christensen, L. $\mathrm{K}$., Detection of nitrogen deficiency in wheat from spectral reflectance indices and basic crop eco-physiological concepts. Aust. J. Agric. Res., 2006, 57(7), 781-789.

61. Rouse Jr, J. W., Haas, R. H., Deering, D. W., Schell, J. A. and Harlan, J. C., Monitoring the Vernal Advancement and Retrogradation (Green Wave Effect) of Natural Vegetation, Technical Report, Texas A\&M University, College Station, TX, USA, 1974.

62. McFeeters, S. K., The use of the normalized difference water index (NDWI) in the delineation of open water features. Int. J. Remote Sensing, 1996, 17(7), 1425-1432.

63. Rondeaux, G., Steven, M. and Baret, F., Optimization of soiladjusted vegetation indices. Remote Sensing Environ., 1996, 55(2), 95-107.
64. Richardson, A. J. and Wiegand, C. L., Distinguishing vegetation from soil background information. Photogramm. Eng. Remote Sensing, 1977, 43(12), 1541-1552.

65. Garbulsky, M. F., Peñuelas, J., Gamon, J., Inoue, Y. and Filella, I., The photochemical reflectance index (PRI) and the remote sensing of leaf, canopy and ecosystem radiation use efficiencies: a review and meta-analysis. Remote Sensing Environ., 2011, 115(2), 281297.

66. Merzlyak, M. N., Gitelson, A. A., Chivkunova, O. B. and Rakitin, V. Y., Non-destructive optical detection of pigment changes during leaf senescence and fruit ripening. Physiol. Plant, 1999, 106(1), 135-141.

67. Gupta, R. K., Vijayan, D. and Prasad, T. S., Comparative analysis of red-edge hyperspectral indices. Adv. Space Res., 2003, 32(11), 2217-2222.

68. Guyot, G. and Baret, F., Utilisation de la haute resolution spectrale pour suivrel'etat des couverts vegetaux. In Spectral Signatures of Objects in Remote Sensing, 1988, vol. 287, p. 279.

69. Gitelson, A. and Merzlyak, M. N., Spectral reflectance changes associated with autumn senescence of Aesculus hippocastanum L. and Acer platanoides L. leaves. Spectral features and relation to chlorophyll estimation. J. Plant Physiol., 1994, 143(3), 286292.

70. Roujean, J. L. and Breon, F. M., Estimating PAR absorbed by vegetation from bidirectional reflectance measurements. Remote Sensing Environ., 1995, 51(3), 375-384.

71. Major, D. J., Baret, F. and Guyot, G., A ratio vegetation index adjusted for soil brightness. Int. J. Remote Sensing, 1990, 11(5), $727-740$.

72. Huete, A. R., A soil-adjusted vegetation index (SAVI). Remote Sensing Environ., 1988, 25(3), 295-309.

73. Broge, N. H. and Leblanc, E., Comparing prediction power and stability of broadband and hyperspectral vegetation indices for estimation of green leaf area index and canopy chlorophyll density. Remote Sensing Environ., 2001, 76(2), 156-172.

74. Vogelman, J. E., Rock, B. N. V. and Moss, D. M., Red edge spectral measurements from sugar maple leaves. Remote Sensing, 1993, 14(8), 1563-1575.

75. Peñuelas, J., Filella, I., Biel, C., Serrano, L. and Save, R. The reflectance at the $950-970 \mathrm{~nm}$ region as an indicator of plant water status. Int. J. Remote Sensing, 1993, 14(10), 1887-1905.

76. Zarco-Tejada, P. J., Miller, J. R., Noland, T. L., Mohammed, G. H. and Sampson, P. H., Scaling-up and model inversion methods with narrowband optical indices for chlorophyll content estimation in closed forest canopies with hyperspectral data. IEEE Trans. Geosci. Remote Sensing, 2001, 39(7), 1491-1507.

ACKNOWLEDGEMENTS. This work was a part of the M.Sc. degree programme. S.A. thanks Indian Council of Agricultural Research, New Delhi for a Junior Research Fellowship during the study period. The logistic support received from the Director, Indian Agricultural Research Institute, New Delhi is acknowledged.

Received 4 January 2021; revised accepted 5 April 2021

doi: $10.18520 /$ cs/v121/i3/402-413 